\title{
INTEGRATED AGRIBUSINESS IN THE DAIRY INDUSTRY OF UKRAINE: MAIN CHARACTERISTICS AND SUCCESS FACTORS
}

\author{
Anna Gereles \& Dr. Oleksandr Galych \\ Poltava State Agrarian Academy \\ Training and Research Institute of Economics and Business Faculty of Economics and Management \\ Department of Business Administration and Law, 1/3 Skovorody Street, Poltava, 36003 Ukraine \\ anna.sunny.gereles@gmail.com,galychoa@i.ua
}

\begin{abstract}
Ukraine belongs to the TOP 20 global producers of milk. Despite its position, the Ukrainian dairy industry is suffering from a permanent deficit of raw milk supplied for processing. on average, in 2007-2011 over half of the produced raw milk did not reach the processors. one of the reasons behind this lasting trend is that the structure of initial production of raw milk is dominated by households (having a share of $80 \%$ ); the latter produce milk mostly for their own consumption and leftovers are sold at marketplaces where they can get more attractive prices. nevertheless, already today we observe results of largescale investments into the industrial production of milk made in the last few years.

This article stresses an important place of the dairy industry in the agriculture of Ukraine, as it provides the population of vital food products, many of which are strategic in the export potential. Authors present essential characteristics of the concepts "agro-industrial integration" and "agroholding", discloses their role and place in the agrarian sector of the economy, and justifies the necessity of the creation an integrated production in the Ukrainian dairy sub-complex. The study aims at identification and description of latest trends in Ukraine's dairy market. Moreover, authors present a successful Ukrainian example of Milkiland N.V. as one of the TOP 5 players in the Commonwealth of Independent States (CIS) dairy market.
\end{abstract}

Keywords: agroholdings, dairy industry, integrated farms, dairy products, Mililand

\section{Introduction}

Ukraine, being a large European economy, has an alldeveloped industrial base, the rich farmlands, highly trained labour and a good education system. The country possesses a massive high-tech industrial base, including electronics, arms industry, space program and is a major producer of grain, sugar, meat and milk products.

The crisis on international food markets has raised a special attention of experts and business circles towards Ukraine, which is one of few countries that have significant potentials to increase productions of agricultural outputs. Meanwhile, the national farm sector is being affected by some dramatic changes the scale of which can be compared with the reforming of collective farms in the middle 1990s. Producers of milk, manufacturers, and vendors had to overcome the problems connected with a deficiency of financial assets and raw materials, with non-payments, with a decrease of purchasing capacity of the population, with an adverse conjuncture of the world dairy market. Speaking about these changes we mean, first of all, the formation of vertically and horizontally integrated agricultural holdings, which are already present on leading European financial markets and which have already began a hallmark of the national farm sector.

Some other changes relate to global economic processes: in 2008 Ukraine became a member of the World Trade Organization (WTO). On the other hand, undoubtedly, the financial crisis and global corrections on stock and commodity markets impact the farm sector in Ukraine and particularly its dairy industry. These changes will be tangible both on the macro and micro levels. In these conditions, one may be curious to know: What is the present state of the Ukrainian dairy industry, and what kind of changes the sector should be expecting in the futures? This study is aimed at addressing these issues.

\section{Materials and research methods}

The dairy industry takes an important place of the dairy industry in the agriculture of Ukraine, as it provides the population of vital food products, many of which are strategic in the export potential. Milk is our first food, and provides the basic building blocks for good health, with lifelong benefits. 
People know that the calcium in milk helps to build and maintain strong bones and teeth. Milk and dairy products are the richest source of calcium.

Research has identified more than 100 different components in milk. Evidence is mounting that consumption of milk and dairy products may reduce blood pressure, dental cavities and the risk of cancer, while enhancing bone strength and immunity. The global demand for dairy products today is much larger than supply and Ukrainian producers have a real chance to occupy substantial niche of this global dairy market.

The modern state of integration processes in agroindustrial sub-complex and the prospects of their development in market conditions have been attracting the attention of many researchers. Among them there are such Ukrainian scholars as V. Andriichuk, P. Berezivskyy, S. Vasylchak, P. Gaydutskyy, T. Dudar, V. Zinovchuk, M. Ilchuk, M. Malik, P. Sabluk and others. Among the foreign scientists we should call I. Ushachov, I. Minakov, G. Hokman, and D. Hay.

According to these scientists (Kobets 2007), large integrated farms are the most perspective organizational forms of management because of their ability to combine the production, processing and marketing of the agricultural products, to use new technologies that are financially unable to afford for another enterprise's types, to minimize transaction costs, and to optimize the taxation.

In this paper we discuss the major bottlenecks in the dairy sector known in the literature and expressed by the sector players. Also we summarize the main results of the recent empirical studies done on the dairy sector of Ukraine. However, according to the last years' features and trends of the agro-industrial integration in the dairy sub-complex, some approaches require the deepening and adaptation to the modern realities in the specific light of joining Ukraine to the World Trade Organization (WTO).

\section{Results and discussion}

This chapter is dedicated to the short overview of Ukrainian agrarian sector. The strong emphasis is made on the dairy industry with focusing on integration processes in it. Authors present a successful Ukrainian example of Milkiland N.V. as one of the TOP 5 players in the Commonwealth of Independent States (CIS) dairy market.

\subsection{Agrarian Sector of Ukraine}

Agrarian business in Ukraine is one of the few sectors of the economy that successfully survived global economic crisis of 2008-2009 years. Agricultural output has practically not diminished as compared to pre-crisis level, and the latter is going to be surpassed already in 2011, with moderate growth in livestock sector and relatively good harvest of main crops.

Over the last year, there have been remarkable changes in Ukraine's agriculture. Increase of intensity of production, re-orientation towards more profitable crops and commodities, expansion to foreign markets, development of agrarian holdings and attraction of investments on international stock markets - all these contributed to turning of Ukraine's agriculture into the most attractive sector of the economy.

The year of 2011 may be featured as a period of postcrisis growth in Ukraine. Compared with 2010, when gross domestic product (GDP) gained 4.2\%, in 2011 GDP growth made up $5.2 \%$. The agrarian sector contributed heavily to this positive trend: growth of gross output of agricultural production amounted to $17.6 \%$ as compared with 2010 . This impressive level of growth was, to a large extent, explained by the record harvest of cereals.

During 2011 the share of the agrarian sector in GDP also increased, from $7.6 \%$ up to $8.3 \%$, following the trend of recent years of featuring steady enlargement of the share of agriculture in gross value added. Stability of prices and tariffs facilitated a low level of food prices inflation in 2011. Another important reason for low consumer price index was the high yield of grain crops and horticultural products due to very favorable weather conditions.

The best evidence of sector's development is the fact that it increased its output by $27 \%$ (starting from 2000) without expansion of crop areas (see Figure 1). At the same time, low productivity, outdated physical infrastructure and technologies, lack and high cost of lending resources, ineffectiveness of management and state agrarian policy missing predictability have prevented stable growth at high rates.

And now let focus on the efficiency of livestock farming. As we may see in Figure 2, efficiency of production of main types of animal products in Ukraine is quite poor. The only exception is made by aviculture (poultry meat and eggs) where production is concentrated mostly on farms employing

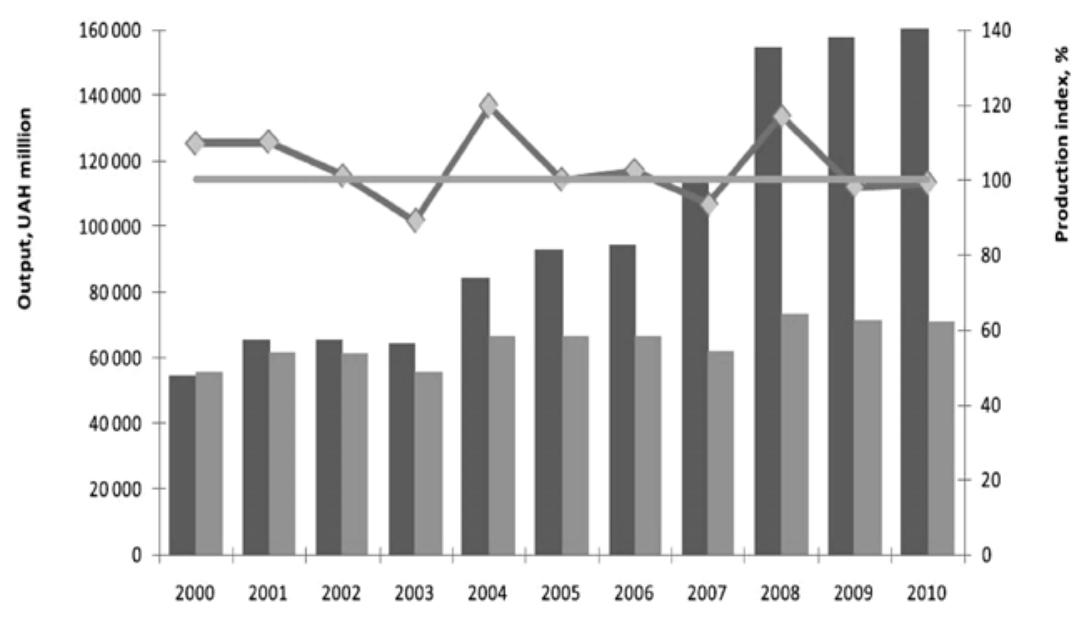

Nominal agricultural output, UAH million Real agricultural output (in prices of 2000), UAH million

Figure 1: Gross agricultural output of Ukraine, 2000-2010 Source: State Statistic Service of Ukraine 


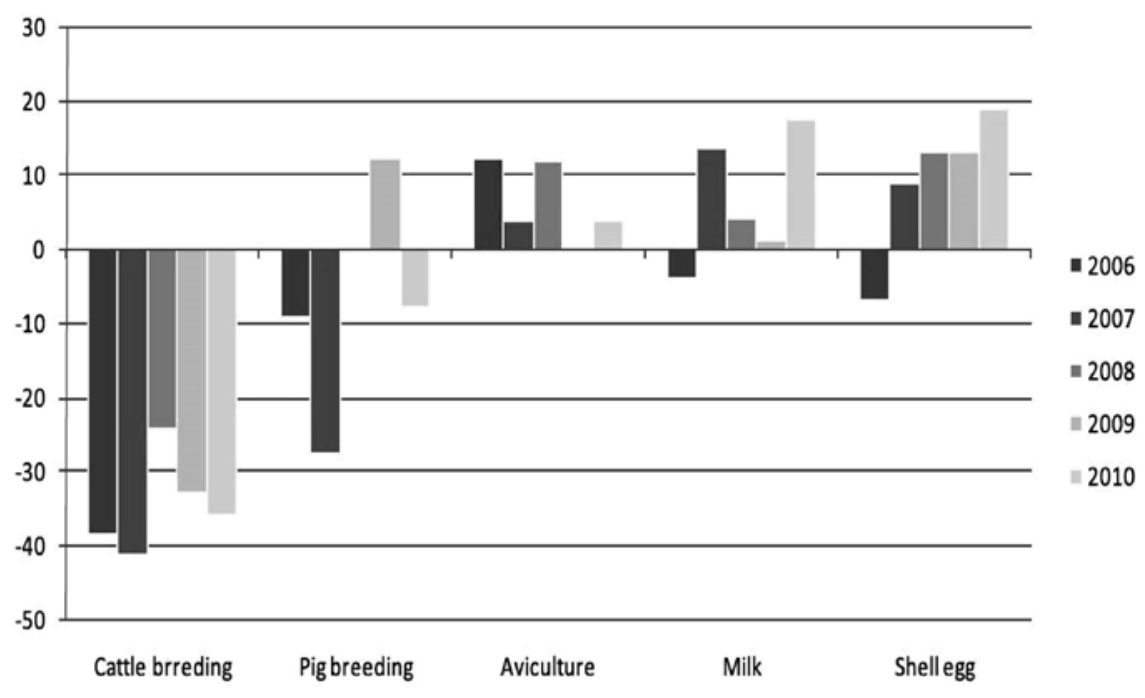

Figure 2: Profitability of livestock breeding at agricultural enterprises of Ukraine, \% Source: State Statistic Service of Ukraine

high technologies. Production of milk due to a deficit of milk on the Ukrainian market reported certain profitability but, due to inseparability of efficient dairy production with inefficient rising of young cattle, the overall result of dairy farms is mostly negative.

Poor genetics of pigs, imbalanced feed, low efficiency of labour are key drawbacks of Ukrainian pig breeding sector which, combined with deterioration of prices for pigs on the domestic market, have driven the sector back at running at a loss. Only few farms, employing the most advanced technologies, look into the future with confidence.

\subsection{Overview of Ukrainian dairy industry}

According to United Nations Food and Agriculture Organization (FAO), global dairy market has one of the most upward growth potential the total food market. The key growth drivers are demands from Asian countries, Russia, Ukraine and Belarus. In 2011, global dairy production reached 728 million tons, representing a $2 \%$ increase over 2010. Most of the increase comes from developing countries, in particular Argentina, China and India. At the same time, import demand grew $5.4 \%$ to 49.5 million tons. Growing world population puts a challenge for world milk production.

As for the Ukrainian dairy industry, it is based on "three whales", or three main directions of activities: whole milk output, cheese, and butter (plus milk powder and casein). Cheese and butter are the most raw stock consumption intensive products, though whole milk output is considered to be the most important, because it is a staple commodity. Steady rise in the production volumes of practically all major dairy products is observed in Ukraine regardless of the commodity importance. The production of some goods increased several times lately with the most significant increase seen for cheese.

Annual milk yield during the Soviet era in Ukraine was over 20 million tons, and the industry's reorganization has yet to regain these heights. With such potential, Ukraine could have been an absolute leader of milk procurement in Europe. The disastrous reduction in livestock herds and decrease in dairy herd productivity since independence played havoc on the sector. As a result, only 12,6 million tons of milk were collected in 2000 that was half of 1990 year index. However, the situation started to improve in the end of 1990s. Milk production volumes in Ukraine stabilized at the level of 13,7-13,8 million tons over recent years. The slide in milk production stopped because of yield in family farms. Meanwhile, milk yield in commercial agricultural farms dropped many times.

Long-lasting invariably downward trend in dairy sector - in terms of population of cows and in terms of milk production - has already led to the situation when deficit of milk for industrial processing became very acute. However, if one looks at official statistics on production of milk in households and on corporate farms and compares them with data on industrial processing by regions, it turns out that all regions do have excess of milk. But in some regions, like Mykolayiv, Kherson, Kyiv, Cherkasy, Poltava and Sumy regions, competition of processors over milk may be more acute as the share of supply for processing accounts for $60 \%$.

At the same time, if we look at production and processing of milk originating from agricultural enterprises, taking into account that the later are constantly increasing supply, we will conclude that demand for milk from agricultural enterprises is significantly exceeding output in some regions (see Map 1).

Despite the fact, that Ukraine belongs to the TOP 20 global producers of milk, the Ukrainian dairy industry is suffering from a permanent deficit of raw milk supplied for processing.

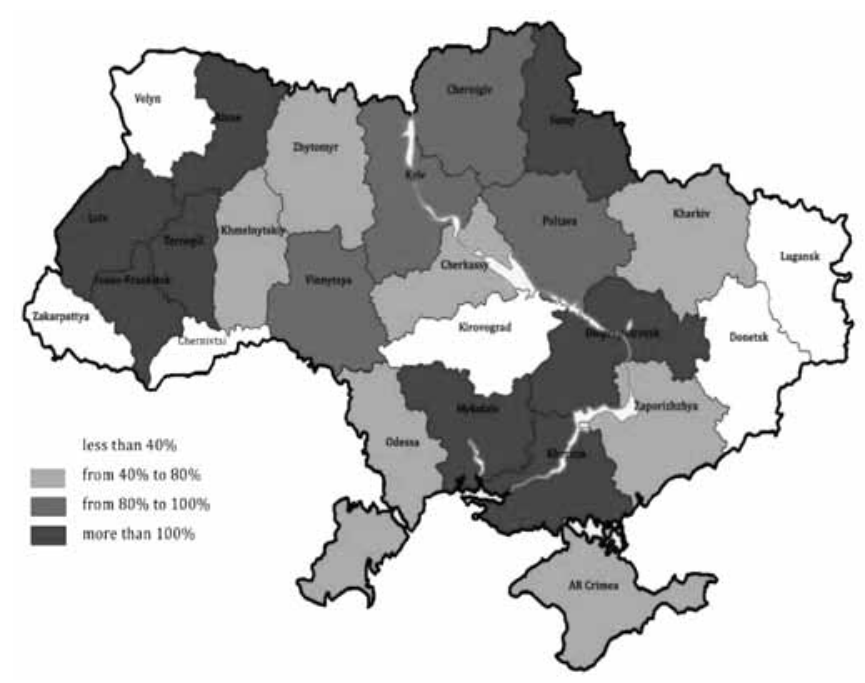

Map 1: Share of milk supplied for processing by agricultural enterprises, $\%$ of the total production, 2011 Source: "Ukrainian Agribusiness Club" 
On average, in 2007-2011 over half of the produced raw milk did not reach the processors.

At that, agricultural enterprises are undergoing essential structural changes. So, the group of enterprises with an annual output below 2 thousand tons is reporting reduction of production while large farms are reporting increase of milk output by $8 \%$. Unfortunately, achievements of the later group could not make up for failure of the former.

One of the reasons behind this lasting trend is that the structure of initial production of raw milk is dominated by households (having a share of $80 \%$ ); the latter produce milk mostly for their own consumption and leftovers are sold at marketplaces where they can get more attractive prices. Nevertheless, already today we observe results of largescale investments into the industrial production of milk made in the last few years.

It is necessary to mention that in 2011 there were 22 agroholdings with an annual production of milk exceeding 5 thousand tons at each of them (medium and large independent producers are not taken into consideration) (Statistic Yearbook "Agriculture of Ukraine 2011"). Their share in the overall milk output (only agricultural enterprises) accounted for $18.1 \%$. Besides farms belonging to holdings, there were 30 independent producers with the same scale of production. Their market share slightly exceeded $13 \%$. The trend toward enlargement and concentration has been irreversible throughout the last years.

Among positive trends, there is also an increase of the share of milk of extra quality in the overall output of agricultural enterprises (large and medium producers are those having gross annual yield of milk at the level of 10 and 5 thousand tons respectively); it accounted for $7.4 \%$ in the first quarter of 2011 (against $4 \%$ in the same period of 2010). But most milk is still supplied as milk of high (35.1\%) and first $(53.8 \%)$ grade. At that, households manage to supply mostly milk of the second grade (63\%); less than $1 \%$ is qualified as extra quality milk.

Lack of long-term strategy for the development of dairy sector and production of milk, missing state programs for support of implementation of the said strategy along with volatility of prices, absence of long-term contractual relations between producers and processors and poor culture of discharge of contractual obligations are pushing processors towards investments into milk production. Investment projects are not limited to traditional advanced payments, provision of interest-free loans and compensation of interest rates; they also include construction of new livestock breeding complexes and establishment of servicing cooperatives in the private sector etc.

According to results 2011, 11,1 million tons of milk were produced in the country (see Table 1). The dairy industry of Ukraine totals over 450 enterprises, but recently only about 250 dairy plants/ enterprises really process large volumes of milk (over 6 million tons). But from the market and macroeconomic perspective, 2011 was challenging to CIS dairy processors. The upward pressure on costs and unfavourable macroeconomic trends tested their margins.

First of all, Ukraine is a netexporter of dairy products, supplying annually 1 million tons thereof in terms of milk. Naturally, Ukrainian dairy producers are looking at world prices in order to stay competitive on the global market. Besides, from 2005 and on there have been so-called "cheese wars" going on between Ukraine and Russia, the latter is the main trade partner of Ukraine in respect to dairy products. Due to the embargo that is from time to time imposed by Russia on import of Ukrainian dairy products, some volumes of milk meant for the Russian market exert pressure on the domestic market.

Secondly, the milk segment is highly sensitive to any changes in the system of state support and regulation. The scheme of support of milk producers changed twice between 2010 and 2012. The Tax Code of Ukraine adopted in December 2010 provided for subsidies paid per cattle's head; a year later, in December 2011, The Tax Code was altered and former system of support was restored. Experience shows (and not only Ukrainian), that the most effective schemes are those that support the whole supply chain.

So, the mutual relationship among partners in dairy products sub-complex covers all the stages of manufacturing final produce, at all levels: management, organization, production, transportation, processing, storage and selling. Causes, contents, scope, functioning and the task of relationships allow to distinguish three basic types among them: production, organizational and financial (Butko 2010).

Table 1: Ukrainian Dairy Sector, 2007-2011

\begin{tabular}{|l|c|c|c|c|c|}
\hline \multicolumn{1}{|c|}{ Indicators } & 2007 & 2008 & 2009 & 2010 & 2011 \\
\hline $\begin{array}{l}\text { Milk yield, all producers, million t, } \\
\text { including: }\end{array}$ & 12,3 & 11,8 & 11,6 & 11,3 & 11,1 \\
\hline households, million t & 10,1 & 9,7 & 9,4 & 9,1 & 8,8 \\
\hline agricultural enterprises, million t & 2,2 & 2,1 & 2,2 & 2,2 & 2,3 \\
\hline $\begin{array}{l}\text { Milk passed by industrial processing } \\
\text { facilities, million t, including: }\end{array}$ & 6,2 & 6,3 & 6,9 & 6,5 & 6,4 \\
\hline $\begin{array}{l}\text { feeding, losses and other uses of milk, } \\
\text { million t }\end{array}$ & 1,2 & 1 & 1,1 & 1,1 & 1 \\
\hline $\begin{array}{l}\text { own consumption of households and sales at } \\
\text { marketplaces, million t }\end{array}$ & 5,1 & 5,3 & 5,7 & 5,4 & 5,3 \\
\hline $\begin{array}{l}\text { Volume of milk supplied to processing, all } \\
\text { categories of suppliers, million t, including: }\end{array}$ & 6 & 5,4 & 4,7 & 4,8 & 4,7 \\
\hline households, million t & 1,7 & 1,8 & 1,9 & 1,9 & 2,3 \\
\hline agricultural enterprises, million t & 0,9 & 1,1 & 0,9 & 1 & 1 \\
\hline $\begin{array}{l}\text { Export of dairy products, in terms of milk, } \\
\text { million t }\end{array}$ & 0,2 & 0,2 & 0,5 & 0,3 & 0,3 \\
\hline $\begin{array}{l}\text { Import of dairy products, in terms of milk, } \\
\text { million t }\end{array}$ & 10,4 & 9,9 & 9,8 & 9,5 & 9,4 \\
\hline $\begin{array}{l}\text { Overall consumption of milk and dairy } \\
\text { products (in terms of milk), million t }\end{array}$ & & 2,9 & 2,9 & 2,4 \\
\hline
\end{tabular}

Source: State Statistic Service of Ukraine 
The term "integration" is derived from Latin and means combining separate parts into a whole (Andriichuk 2002).

Firstly, the word integration means the organizational combination of technologically interconnected activities with their specific functions to produce the final product and bring it to the consumer, and on this basis to achieve higher economic results.

Secondly, agro-industrial integration means the development of industrial and economic relations between branches and agricultural enterprises, which are interconnected, technologically and objectively by oriented to combine their material interests in the production process and final products from agricultural raw materials' selling (Sabluk and Malik 2002).

In the agricultural production there are three types of integration: horizontal, vertical and mixed. The horizontal integration occurs by consolidating agricultural enterprises for the production of specific products or services for the one purpose. The vertical integration involves combining businesses that operate in different economic sectors for the purpose of circulation of commercial products. It integrates the production, harvesting, transport, industrial processing and marketing. The mixed integration is found in the consolidating companies of different branches, between which there is no the technological and technical connection with the production and sales.

Objective factors that stimulate the development of integration units are:

- unbalanced relations in the agriculture;

- the intermediaries' dominance in the relationship between company en the agriculture and another agricultural branches, and its industrial infrastructure;

- the lack of a clear government policy to support the development of agricultural enterprises;

- the economic monopoly of processing and service enterprises and the inability of the agricultural sector involvement in the pricing process;

- the company at local market's fullness of its own regional products.

All these reasons make the relevance of the development of relevant theoretical and applied principles of integrated production.

The temper factor in integrating of farmers in horizontal and vertical direction is the absence of necessary resources that allow them to be equal partners in associations. It is possible to improve this situation by the state's participation in such processes as the guarantor of property and financial contributions of farmers. Moreover, despite the significant risk in agriculture, it would be good to provide insurance functions from the state.

Among the advantages of the agro-industrial integration we can select the following:

- it provides a single process of production, procurement, storage and processing of products;

- more favorable conditions for the wide application of the scientific and technological progress are created;

- the reducing of administrative personnel is achieved;

- the conditions for interests' combination of all agricultural participants are created;
- there is the possibility of organizing production through the effective saving of all resources;

- the optimal combination of the territorial and sectored management is provides.

However, behind this success, there are rapid processes at the micro level. Here, the least successful businesses have to wind-up and, thus, assets are concentrated in the hands of the more successful companies. Under the conditions of modest state support, the contrast in the operational results of agricultural companies is becoming even more evident. Therefore, the processes of concentration and verticalization that have occurred during pre-crisis times take the bit also today, when the first shock of the crisis is over. Furthermore, the investment attractiveness of the dairy sector is gradually recovering.

So, we decided to show such successful Ukrainian example of Milkiland N.V. as one of the TOP 5 diversified players in the CIS dairy market.

\subsection{Milkiland N.V. - the successful Ukrainian example of the diversified dairy producer}

Milkiland is a diversified dairy producer operating in Russia, Ukraine and Poland. The company offers wide range of dairy products such as fresh dairy, cheese, and butter, to satisfy our consumers in their everyday needs for healthy and tasty foods. Milkiland was founded in 1994 as a small dairy trading business, and since that time has grown into a leading dairy company with strong reputation of high-quality producer. Milkiland has grown by acquiring and modernizing old dairy plants.

Milkiland is proud to produce all-natural dairy from the best milk. Over 1,700 Milkiland's people work every day to collect and deliver fresh milk to 11 plants; 3,500 workers and technologists devote themselves to create traditional and new dairy products for consumers. Every day Milkiland supply over 500 tons of high quality fresh dairy, cheese and butter to more than 10,000 retail stores across Russia, Ukraine and other CIS countries.

In Russia Milkiland produce fresh dairy products at Moscow-based OJSC "Ostankinsky Milk Combine" and sell under Ostankinskaya brand. Also, Dobryana Ukrainian cheese is sold in many Russian cities, including Moscow, St. Petersburg, Voronezh, Nizhniy Novgorod, Saratov, Kaluga, Chelyabinsk, Orel, Ekaterinburg, Omsk, and Kaliningrad. In Poland, Milkiland Group acquired Mazowiecka Spoldzielnia Mleczarska Ostrowia, the cheese production plant located in in Ostrów Mazowiecka town of Masovian Voevodeship of the Republic of Poland.

In Ukraine Milkiland has 10 plants producing wide range of dairy products. Milkiland's cheese, fresh dairy and butter are widely available across all Ukrainian cities under brands Dobryana and Kolyada. Milkiland is also a large exporter of dairy products from Ukraine to over 30 countries. About $80 \%$ of the Group's milk is collected and processed in Ukraine. The list of these plants consists of Sumy Dairy 
Plant, Mirgorod Cheese Producing Combinat, "Menskiy Syr", Mena, "Lactis" Dairy Plant, Kamenets-Podolskiy, Lviv Dairy Combinat, Slavutskiy Butter Producing Combinat, Joint-Stock Company (JSC) "Romenskiy Dairy Combinat", JSC "Konotopskiy Dairy Plant", JSC "Ohtyrskiy Cheese Combinat". Milkiland's business model is outlined in the scheme below (Figure 3):

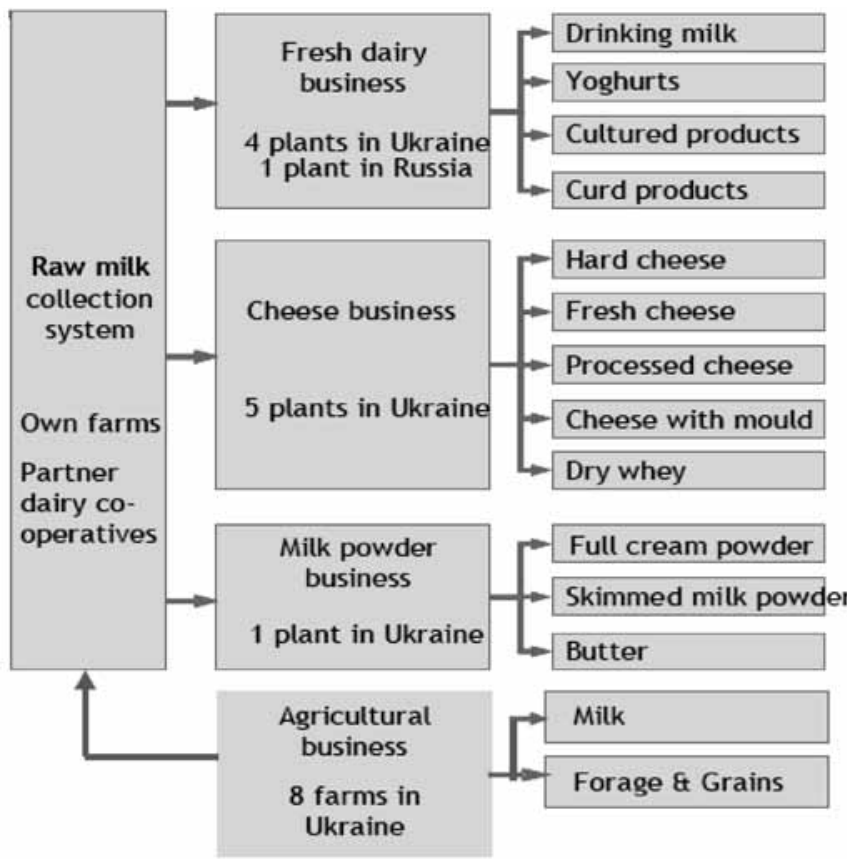

Figure 3: Multiple sales and distribution channels, 2011 Sourse: Aherne F. (2012)

Mr. Anatoliy Yurkevych (the founder of Milkiland Group and CEO of Milkiland N.V.) and Mrs. Olga Yurkevich (a member of the Board of Directors of Milkiland N.V.) though Dutch vehicle 1 Inc. Cooperatief U.A. control $73.52 \%$ of the Milkiland N.V shares. Another 5.0\% of the shares are controlled by Mr. Vyacheslav Rekov, former CEO and current Non-executive Director of Milkiland N.V., though R-Assets Cooperatief U.A. also incorporated in the Netherlands. $21.48 \%$ of the shares of Milkiland N.V. are in the free float at the Warsaw Stock Exchange since December 6, 2010.

The mission of Milkiland is an essential gift of nature to human beings. The company contributes their intellect, labour and passion, to save and deliver the value of milk to people. Milkiland aim to be international, diversified and vertically integrated milk processor offering "value for money" dairy products, and recognizable for its high-quality standards and consumer loyalty. The company plans to serve its consumers with full range of dairy, including affordable everyday food and premium specialty products.

This company picks out three different values, such as:

1. "Living together with our consumers, suppliers and employees". The company lives the same life as people who purchase our products, and people who produce milk. They share their values, aspirations and worries. The company considers them partners in our business. The company is in permanent contact with our partners and make sure their relations are mutually beneficial.

2. "High quality standards". The company feels strongly responsible for products the company delivers, and do not intend to compromise on quality. The company will continuously invest to assure high quality of raw milk, flawless production process, and safe delivery to retail shelves.

3. "Continuous innovation". The company understands that competition is here, and, in order to be successful and earn the consumers' loyalty, the company is to be innovative in all areas of our business, including milk collection, motivation and professional development of its people, introduction of new products, and marketing.

The main strategy of Milkiland is being one of the largest dairy players in the CIS, the company believes that the company can benefit from significant market growth potential and fragmented competition, by identifying attractive consolidation opportunities and continuing our organic growth. In the medium term the company envisages Milkiland as a clear market leader in cheese and one of the leading whole milk producers in the CIS.

Based on Milkiland's established image of high quality producer, the company intend to position ourselves as "supplier of choice" for families, delivering our dairy products from "meadow grass" to people's homes. The company knows how to make products appealing to consumers with their healthy, genuine qualities and superior taste. Also, the company plans to be market leaders in introducing of new products and thus clearly differentiate Milkiland from competition. The company realizes that price and quality of raw milk determine the appeal of end products for consumers. To support Milkiland's growth and ensure quality product offering, the company plans to establish own milk production, in order to eventually satisfy $20-25 \%$ of our internal needs.

Milkiland is active along the dairy value chain. That's why, its business structure looks like:

1. Raw milk supply is important part of business. Almost one-third of employees work on collecting and delivering milk to Milkiland's production units. The company has extensive milk collection system and, in addition, actively develops its own milk farming business. The company plans to increase own milk production, in order to secure high-quality milk for its premium products.

2. Production assets of Milkiland consist of 10 plants in Ukraine, 1 whole milk dairy plant in Moscow, Russia and cheese plant Mazowiecka Spółdzielnia Mleczarska Ostrowia in Mazowian Voivodship of Poland. Milkiland's processing capacity stands at more than 1 million tons per year. Milkiland's plants are capable of producing essentially all range of dairy products.

3. The company distributes products nation-wide in Ukraine and in many Russian cities. Milkiland's distribution network includes large retail chains, local retailers, regional distributors, and exports dealers. Most of company's products are sold in large cities of Ukraine and Russia. 
4. The company markets products under recognizable brands with strong reputation for their quality. Milkiland's sales and marketing team works in points of sales to tell consumers about its products and receive instant feedback.

The company produces essentially all range of dairy products including whole milk products, cheese, butter, ice-cream, and different kinds of dry milk powder. Milkiland has 5 fresh dairy plants and 5 cheese-making plants. Also, 1 plant is designed to produce whole milk powder and skimmed milk powder.

Employers of the company are strong believers that continuous improvement and innovations are the key success factors, and follow this modus operandi in product development. One of Milkiland's strong differentiating points is significant offering of in-house developed products that became very popular within consumers.

Milkiland's quality control starts with milk collection and continues throughout the whole chain of milk intake, processing, storage, and delivery to retail. The company is proud to see that its products are highly appreciated by consumers, and continue to build up their credentials in this area. Our strong reputation will reinforce in the near future, as Milkiland plans to become the first Ukrainian dairy company eligible for exports to European Union.

That's why high quality and safety of Milkiland's products is always the primary focus for the Milkiland Group. The company controls the whole supply chain - from farm to people's homes, and thus ensures high quality of our natural, healthy and tasty dairy products. In order to ensure this, the Group introduces state-of-the-art technology at its dairy production assets. We develop the in-house dairy farming to get the highest quality raw milk for our products.

Milkiland's focus on quality is supported with quality management and safety systems based on ISO 9001, ISO 22000 and HACCP standards introduced at Milkiland's factories, as well as a rigid control over procedures enforced by these standards. While Milkiland is an international business with operations in Ukraine, the EU and Customs Union, it both apply norms and laws of the countries of operations and make sustainable efforts to meet the requirements of the European Parliament and European Council Directives and Customs Union Regulations on food safety.

Milkiland is significant player in whole milk products, being one of the largest producer in Ukraine and the $3 \mathrm{~d}$ player on Moscow market. The company markets its whole milk products under Dobryana and Kolyada brands in Ukraine, and under Ostankinska brand in Russia. Also, the company produces private label products for major retailers such as X5 and Metro (see Figure 4).

There is the list of all products, which the company produces.
Hypermarket and supermarket chains active in the CIS

22 key accounts in 2011, including Metro, X5, Auchan, Fozzy and Furshet

- Key distributors of cheese and dry milk products abroad

- Access to regions where Milkiland is not represented directly in local retail

Local retail chains, groceries and outlets

Important sales channel for fresh whole milk products

HoReCa

Industrial clients

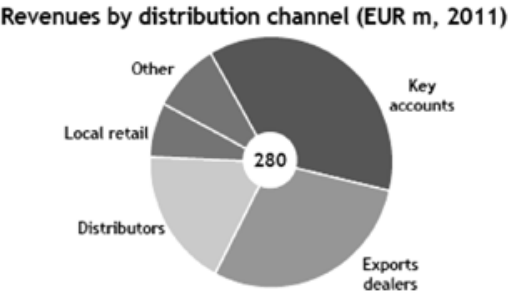

Selected key accounts
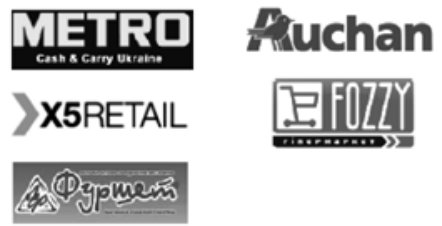

Figure 4: Multiple sales and distribution channels, 2011

Sourse: Aherne F. (2012)

Dairy drinks. The company offers wide variety of traditional dairy drinks such as sterilized and pasteurized milk, kefir, ryazhenka. Also, the company developed and introduced whey drink that is gaining popularity among our consumers.

Food, snacks, dressings. Milkiland is a big producer of cream, sour cream, and cottage cheese - widely popular local type of cottage cheese. Also, the company restored and introduced to the market old traditional thermostatic products such as prostokvasha and varenets.

Desserts. Milkiland's coated and glazed curds, cottage cheese cakes, and desserts are admired by adults and younger population. In addition to its mainstream brands, the company sells dessert under children Fibo brand.

Yoghurts. Milkiland takes part in high growing yoghurt segment, and offers a wide selection of drinkable and spoonable yoghurts in different types of packaging.

Cheese. Milkiland is significant player in whole milk products, being one of the largest producer in Ukraine and in Moscow. The company is one of the leading cheese company in Russia and Ukraine producing over 30 thousand tones of cheese annually. With over 60 types of cheese produced, Milkiland has the most extensive product offering among local players. All cheese is sold under Dobryana and Kolyada brands in Russia, Ukraine, Kazakhstan, and Moldova.

Hard cheese. This is Milkiland's core product in cheese category, as Ukrainians and Russians consume hard cheese in the biggest amounts. The company produces all types of hard cheese and have significant share of in-house developed products. The flagship proprietary cheese, King Arthur, has become very popular both in Russia and Ukraine, and grows in sales by double-digit rate every year.

Specialty cheeses. This group includes white mould cheeses (like Camembert, Brie), blue mould cheeses (like Roquefort, Duplet) and Parmesan-type. These products are new to Ukraine and Russia, however, quickly gaining popularity and are the leaders in consumption growth. Milkiland is the only local producer in this attractive segment, and holds a leading position in Ukrainian market. 
Fresh cheese. The company offers to consumers 6 types of traditional (like brynza) and newly introduced fresh cheese products (like Mozzarella). This segment is in its early stage in CIS, but set to grow quickly, as healthy European diet is getting more appealing to local population. The company plans to invest in this area and lead the segment with existing and new products.

Processed cheese. To satisfy the needs of consumers for different cheese products, the company produces 16 types of processed cheese.

Butter. The company offers to our consumers a wide range of dairy butter, made according to best recipes and remarkable for its delicate and sweet flavour. The company sells butter under Dobryana brand, reinforcing this product offering of cheese and whole milk products to Ukrainian and Russian families.

Milkiland is also a large supplier of bulk butter to industrial customers such as confectionery, bakery etc, in Ukraine and abroad.

In 2011 Milkiland delivered strong growth in cheese \& butter segment, as well as in dry milk products, in terms of both volume and price. As a result of these developments, revenue grew by $10 \%$ to EUR 280 million driven by stronger markets and better sales. Gross profit was depressed by $18 \%$ on to EUR 80 million a backdrop of de-facto cancellation of the government subsidies to dairy industry in Ukraine and high raw milk prices in Russia, and the impact of the depreciation of the Russian Rouble.

Apart from agricultural segment development, in 2011 Milkiland started to support milk cooperatives established in the regions of the Groups' operations. In total, 16 cooperatives in 12 regions of Ukraine started their operations in 2011 supported by Milkiland (see Map 2). They provide veterinary services, feed, financial aid and training to their members aiming at higher milk output and quality. Starting from June 2011 , by the end of the year, they attracted over 17,000 members and accounted for more than 21,000 milking cows. The share of cooperative milk in the total milk collection in Ukraine reached 18\% in December 2011 and amounted to 6\%

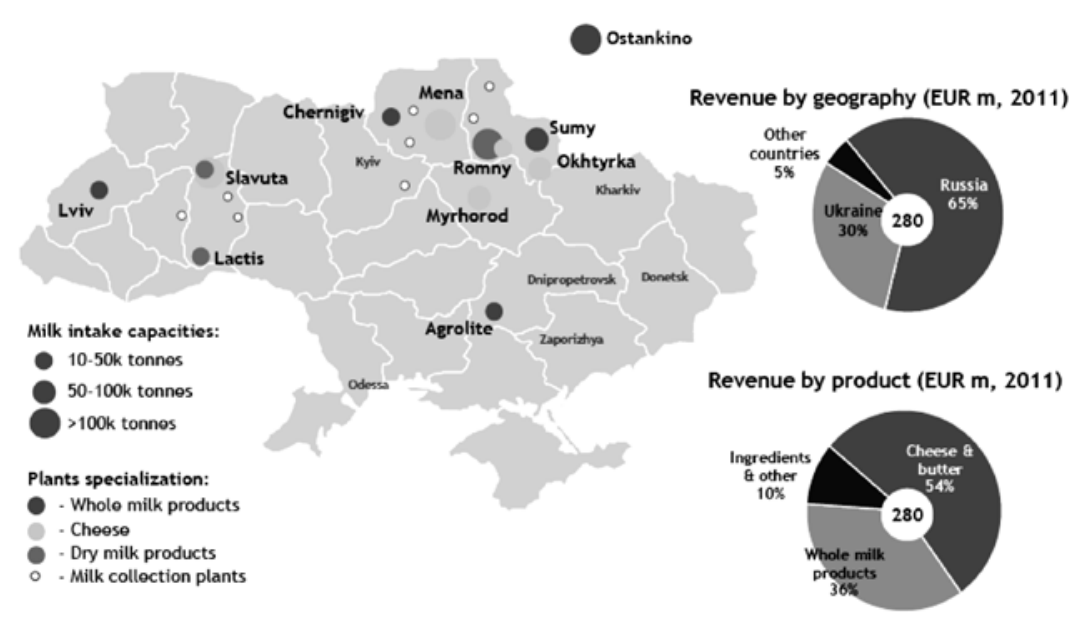

Map 2: Milkiland Group, 2011 Sourse: Aherne F. (2012) for the whole year. In 2012, cooperatives should provide for over $20 \%$ of raw milk collected by Milkiland in Ukraine.

On the cost-side, the new milk sourcing system launched in 2011 will be further developed. Two new state-of-the-art cattle farms will be constructed to house 6,000 milking cows in order to boost the in-house milk production. Such an increase will provide for higher profitability for the group since production costs for in-house milk are $50 \%$ cheaper than that purchased from farms. Developing in-house milk production is also a vital factor towards quality control.

On the product mix-side, Milkiland will continue product mix optimization towards modern products with higher marginal contribution. The Group's marketing efforts will be focused on promotion of cheese and thermostatic products under Dobryana brand.

The Group's development will be financed with IPO proceeds and borrowings. In December 2011, the Group signed a new syndicated loan agreement with a syndicate of international banks. The financing in an amount of up to USD 100 million comprise a senior secured long term loan for 4 years with a 12-month grace period. The availability period for loan drawdown is 9 months (270 days). The proceeds from this facility will be used to repay the existing Ukrainian banks loans (USD 35 million) and for general corporate purposes, including working capital needs.

In August 2012 Milkiland acquired Mazowiecka Spoldzielnia Mleczarska "Ostrowia", a cheese production plant located in Ostrów Mazowiecka of Masovian Voivodeship, Republic of Poland.

Ostrowia is an advanced cheese making facility capable of producing wide range of dairy products essential to Milkiland, including hard cheese, curd cheese, yoghurts and processed cheese. In 2003-2007, the Ostrowia undergone major modernization and currently comprises a state-of-theart cheese plant. Ostrowia brand is well known in the Polish market and abroad.

Ukrainian dairy processor Milkiland paid USD 15 million for the assets of bankrupt Polish cheesemaker Mazowiecka Spółdzielnia Mleczarska "Ostrowia". Milkiland plans to invest USD 4 million in the company's idled manufacturing facility in Ostrów Mazowiecka, Poland, which underwent a full upgrade and modernization from 20032007, to manufacture cheese for export to Commonwealth of Independent States countries. The facility has a capacity of 15,000 tons of hard cheese, 7,000 tons of processed cheese and 11,000 tons of yogurts per year.

To our opinion, Ostrowia is a perfect addition to Milkiland's asset base and after launching investments will become one of the largest and best equipped cheese making facilities of Milkiland. This acquisition will bring new international exposure to the business of our Group. With Ostrowia, Milkiland will combine its in-depth knowledge of CIS dairy markets with advantages of Polish 
dairy sector, such as developed milk supply base, reasonable costs and advanced dairy technologies. Poland is already one of the largest dairy exporter in EU, and Milkiland will turn its still untapped potential to CIS markets, primarily Russia and Ukraine. Also, with Ostrowia, Milkiland opens a door to a tremendous EU dairy market, with long term opportunities for growth and business diversification.

Nowadays in Ukraine the most interesting topic for discussion is the "cheese question". In January 2012, Mr. Gennadiy Onischenko, Chief of Russian Federal Service on Customers' Rights Protection and Human Well-Being Surveillance (Rospotrebnadzor), made a number of statements in respect to poor quality of government quality control systems and, specifically, sub-par quality of Ukrainian cheese exported to Russia. Such statements of Mr. Onischenko were protested by Ukrainian authorities and exporters; a number of independent tests were made and provided to Rospotrebnadzor in order to dismiss allegations.

Public escalation of this conflict resulted in restrictions imposed on three largest Ukrainian exporting plants, including Milkiland's Mena plant. A number of meetings between involved parties (sanitary authorities from both countries, as well as cheese exporters) were held in order to settle the issue.

On April, 9, 2013 Federal Service on Customers Rights Protection and Human Well-Being Surveillance (Rospotrebnadzor) announced simplification of control procedures for exports of Ukrainian cheese to Russian Federation. According to Rospotrebnadzor, from now on there is no need for control of each shipment of exported cheese. This decision was adopted based on laboratory tests of 1260 samples of Ukrainian cheese, made during 2012-2013, which have confirmed the compliance of the checked products with the requirements of the Russian Federal Law dated 12 June 2008 "Technical regulations of milk and milk products". Rospotrebnadzor will continue control of quality of the Ukrainian cheese along with the regular approach envisaging retail outlets sampling.

By the way, this year independent experts prove the quality of Milkiland cheese exported to Russia. Milkiland's cheese Vershkovy (Creamy), Smetankovy, Marble and King Arthur sold under Dobryana trademark have been tested by Russia's leading independent testing institution "Soyuzekspertiza" of the Russian Chamber of Commerce. Results of the fat acid tests show that all samples tested fully comply with the Russian technical regulations for milk and dairy products.

Taking into the account, that Milkiland's Mena plant is one of the best equipped cheese facilities in Ukraine certified according to EU standards, which is also fully fulfills Russian technical and safety standards, Milkiland is positive about prompt removal of the export limitations for this facility.

In this case, economic impact on Milkiland would be minor, because other exporting plants (Okhtyrka and Romny) can satisfy low-season export volumes, losses associated with temporary low volumes of cheese exports should be compensated by a respective decrease in raw milk price, which already took place in Ukraine from the beginning of 2012.

\section{Conclusions}

The dairy sub-complex occupies an important place in the agriculture of Ukraine, as it provides the population of vital food products, many of which are strategic in the export potential. Unique properties of milk and its processing products lead to the necessity of consumers' uninterrupted provision of such products, which requires the effective functioning of the dairy sub-complex.

According to results 2010, 12,2 million tons of milk was produced in the country. The dairy industry of Ukraine totals over 450 enterprises, but recently only about 250 dairy plants/enterprises really process large volumes of milk (over 6 million tons). Experience shows (and not only Ukrainian), that the most effective schemes are those that support the whole supply chain.

Good example of such scheme shows Milkiland Group. It is a diversified dairy producer operating in Russia, Ukraine and Poland. The company offers wide range of dairy products such as fresh dairy, cheese, and butter, to satisfy our consumers in their everyday needs for healthy and tasty foods. Milkiland was founded in 1994 as a small dairy trading business, and since that time has grown into a leading dairy company with strong reputation of high-quality producer. Milkiland has grown by acquiring and modernizing old dairy plants.

Milkiland is proud to produce all-natural dairy from the best milk. Over 1,700 Milkiland's people work every day to collect and deliver fresh milk to 11 plants; 3,500 workers and technologists devote themselves to create traditional and new dairy products for consumers. Every day Milkiland supply over 500 tons of high quality fresh dairy, cheese and butter to more than 10,000 retail stores across Russia, Ukraine and other CIS countries.

The company produces essentially all range of dairy products including whole milk products, cheese, butter, icecream, and different kinds of dry milk powder. Milkiland has 5 fresh dairy plants and 5 cheese-making plants. Also, 1 plant is designed to produce whole milk powder and skimmed milk powder.

Milkiland's quality control starts with milk collection and continues throughout the whole chain of milk intake, processing, storage, and delivery to retail. The company is proud to see that its products are highly appreciated by consumers, and continue to build up their credentials in this area. Our strong reputation will reinforce in the near future, as Milkiland plans to become the first Ukrainian dairy company eligible for exports to European Union.

Apart from agricultural segment development, in 2011 Milkiland started to support milk cooperatives established in the regions of the Groups' operations. In total, 16 cooperatives in 12 regions of Ukraine started their operations in 2011 supported by Milkiland. They provide veterinary services, feed, financial aid and training to their members aiming at higher milk output and quality. Starting from June 2011, by the end of the year, they attracted over 17,000 members and accounted for more than 21,000 milking cows. The share of cooperative milk in the total milk collection in Ukraine 
reached 18\% in December 2011 and amounted to 6\% for the whole year.

The new year brings new opportunities and new challenges to dairy business. The re-introduction of the government subsidies to raw milk producers by the Ukrainian Parliament from 1 January 2012 led to a decline in input costs for dairy production, which should positively influence the producers. The major challenge for dairy business is the on-going dispute with Russia regarding quality of the Ukrainian dairy products exported to this country. Some limitations imposed by Russian authorities (Rospotrebnadzor) on export of this product to Russia could weaken dairy producers' positions in this market.

Milkiland's management believes that theirur strong commitment and constant efforts to deliver the Group's development strategy will bring positive results, new prospects and will strengthen its positions as TOP-5 CIS diary market player.

\section{References}

Aherne F. (2012): Milkiland: Preliminary overview of 2011 results and 2012 outlook. Kiev, p. 30.
Andriichuk V. (2002): Economics of agricultural enterprises. Kiev: KNEU. p. 624.

Association “Ukrainian Agribusiness Club” 2011: Doing Agribusiness in Ukraine. Issue 4. Kiev, p. 60.

Butko M. (2010). The agro-industrial integration as a way to enhance the agricultural production. Agrosvit. Issue 3, pp. 10-13.

Kobets E. (2007): The historic aspects of the integration, its forms and directions. The State and Regions. The Series: Economics and Business. Issue 2, pp. 129-133.

Nivievskyi O., Ilienko I., Ryzhkova M. (2008): Dairy supply chain in Ukraine: bottlenecks and directions for development. Poster Paper presented at IAMO Forum 2008. Halle (Saale): Leibniz-Institut für Agrarentwicklung in Mittel- und Osteuropa (IAMO), p. 130.

Sabluk P., Malik M., Valentines V. (2002): The inter-relationships' formation: problems of the theory and methodology. Kiev: IAE. p. 294.

Statistic Yearbook "Agriculture of Ukraine 2010" (2011). Kyiv: State Statistic Service of Ukraine, p. 374.

Statistic Yearbook “Agriculture of Ukraine 2011" (2012). Kyiv: State Statistic Service of Ukraine, p. 406.

Available on the web at: http://www.ukrstat.gov.ua/

Tsymbal V. (2010): In a single impulse: agricultural holdings. AgroPerspective. Issue 2, pp. 20-27. 